\title{
The systems method as an educative tool for sustainable architecture design on the example of solar building design
}

\author{
Janusz Marchwiński \\ j.marchwinski@wseiz.pl | @ https://orcid.org/0000-0003-3897-3580 \\ University of Ecology and Management in Warsaw, Faculty of Architecture
}

Scientific Editor: Mateusz Gyurkovich, Cracow University of Technology Technical Editor: Aleksandra Urzędowska, Cracow University of Technology Press Language Editor: Timothy Churcher, Merlin Language Services Typesetting: Małgorzata Murat-Drożyńska, Cracow University of Technology Press

Received: May 26, 2021

Accepted: December 18, 2021

Copyright: ๑ 2021 Marchwiński. This is an open access article distributed under the terms of the Creative Commons Attribution License, which permits unrestricted use, distribution, and reproduction in any medium, provided the original author and source are credited.

Data Availability Statement: All relevant data are within the paper and its Supporting Information files.

Competing interests: The authors have declared that no competing interests exist.

Citation: Marchwiński, J. (2021).

The systems method as an educative tool for sustainable architecture design on the example of solar building design. Technical Transactions, e2021026. https://doi. org/10.37705/TechTrans/e2021026

\begin{abstract}
The following article discusses the systems method as an educative tool for teaching sustainable architecture, including environmental design. Based on this method, a systemic model was created which provided a pillar of the learning process that concluded with a solar building project. This method offered a holistic view of the issues of pro-environmental design and led to an understanding of the relationship between the urban scale and the scale of the building. This aspect was considered crucial in teaching sustainable development architecture.

The systems method has been recently used in China as a part of an environmental design course which only lasted for forty-eight lesson hours. The method proved to be an effective educational tool that enabled the obtaining of satisfactory design effects in such a short period of time. Additionally, the method was successful in conditions of cultural and linguistic barriers and a lack of prior preparation of students in the field of architectural design. The created systems model determined a precisely defined path for the teaching process in advance, as the specified issues included only those that were needed to achieve the set project goals. This approach resulted in the optimisation of teaching time, while ensuring the completeness of the assumed results.

Experience gained from the didactic process leads to the conclusions that the systems method can be an adequate educative tool for solving multidisciplinary problems. Based on the example of solar building design, a systems method made it possible to indicate three main external factors that influence the design: macro-scale urban elements (district scale), micro-scale urban development (housing estate) and climatic conditions. The article also presents the possibilities of transforming the system model, in order to facilitate its more universal application, with reference to such issues as the topic of classes, as well as to the required scope and level of detail of the design task.
\end{abstract}

Keywords: sustainable architecture, environmental design, systems method, solar building, architectural education, BIPV 


\section{Introduction}

contemporary architecture is characterised by a growing number of problem areas, among which, ecological issues and energy-related problems play a prominent role. Design issues related to sustainable architecture, including solar PV integrated (BIPV) buildings, call for consideration of problems beyond traditional architectural knowledge (Iwaro et al., 2015). It is necessary to refer to the context of place, and thus to include the issue with regards to the design in macro scale, i.e. spatial- and urban planning. (Bala, 2010; Marchwiński \& Zielonko-Jung, 2005). This phenomenon can particularly be observed in the urban context, in which the set of factors that affect the building is multiplied (Zielonko-Jung, 2019; Zielonko-Jung \& Marchwiński, 2017).

Growing numbers of new specialties have brought classical science (Galileo, Descartes, Newton) to a critical condition. As a result, nowadays, classical science may be seen as the sum of monodisciplines isolated from each other (Wilisz, 2019). Specialisations within a given discipline have developed their own methodologies and even separate languages. This hinders the cooperation between scientists on a multidisciplinary level. The atomisation of science, as the above phenomenon is called (Laszlo, 1996) should be seen as an intensifying process. Architecture, being a discipline that borders art and technical sciences, is subject to the process (di Batista, 2006) and so is sustainability as a global multidisciplinary concept (Gürel, 2010; Poveda \& Lipset, 2014) The complexity of issues (incl. environmental design factors, such as climate, energy etc.) is emphasised in the context of education in sustainable development (Richter \& Sousa, 2019; Shulla et al., 2020). All the above factors make the integrated approaches to sustainability difficult to implement (Hills, 2001; Filho et al., 2018).

The systems method opposes the classical method. It assumes that a set of interrelated elements is the subject of the study. Mutual interactions that affect the properties of the entire object occur between these elements. The method enables limiting of the descriptive cognitive factor and makes it possible to focus on the interactions between the studied elements of the system. The concept is not a new one, but only since the mid-twentieth century has the systems method, as a scientific method, been developed to such an extent that it can be described as a general theory of systems (Polański, 1978). The method is currently described as a tool for new science capable of integrating atomised branches of knowledge.

In relation to sustainability and environmental design, the systemic approach is presented in studies by, for example, Kerdanghan et al. (2012), Lee (2014), Marchwiński (2005), Nikken Sekkei (2000), Sandri (2013), Stiny and Mitchell (1978) and Szparkowski (1978). Educational values of the systems method are well acknowledged (Wilisz, 2019; Togo \& Lotz-Sisitka, 2013). As stated by Mazur (1976, p.17), this tool "allows us to present unclear matters by cyber means (...) the accuracy, conciseness and expressiveness of cyber means significantly facilitate absorption of the existing knowledge, which is of great importance in terms of educational activities" [author's own translation]. As far as teaching architectural design is concerned, educational values of this method are discussed in the works of, for instance: Altun and Tyurkay (2006), Johannes (1992), Nsanbayeva (2019) and Sevaldson (2008).

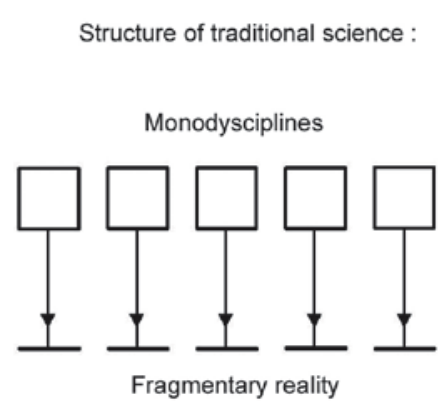

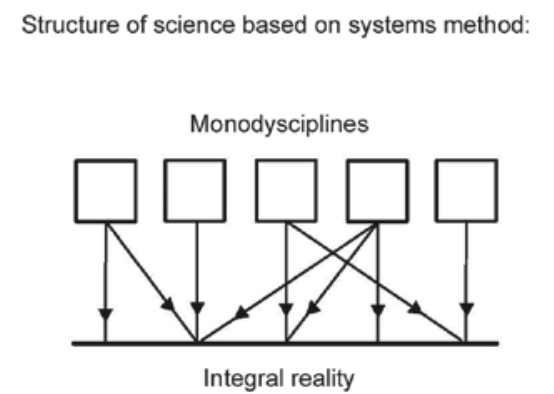

Fig. 1. A schematic representation of the structure of traditional and systems-based science (Mazur, 1976)This article discusses the systems method as an educative tool applied in order to understand the basic principles behind designing solar architecture with BIPV and applying these rules in design. The method makes it possible to explain the complex relationship between the building and its environment, also in relation to spatial planning, urban elements and the climate. Simultaneously, rather than overlooking the essence of the discussed issues, the method focuses exclusively on the selected design problems. 
The systems method has been used experimentally as part of the course in Environmental Design at Zhengzhou University of Aeronautics (China) for second-semester students at the School of Art and Design. The course consisted of twenty lesson hours of lectures and twenty-eight lesson hours of design workshops, according to a program developed by the author. The final effect and practical educative target of the course was to arrive at the architectural design of a solar single family building (including its geometrical form, elevations, closest surroundings). In addition to active solutions, such as building integrated photovoltaics (BIPV), a passive solar solution with an emphasis on the greenhouse structure had to be applied.

The method was chosen because the detailed familiarisation of students with the principles of solar architecture design was neither possible nor justified due to the didactic restrictions. Firstly, students' education profile was not directly related to architecture. Secondly, forty-eight hours of course duration is a relatively short period of time in comparison to the courses held in architectural universities in Poland (where the author teaches). Further obstacles included the language barrier and cultural differences.

The scope of these problems was adapted to the practical preparation of students and the length of the course. In order to achieve the main goals of the course, it was more important for students to gain understanding of the relationships between the solar building in the urban environment and its surroundings. With the use of the systems method, an original, systemic model was created by the author. The model was then applied to provide the basis for the implementation of the didactic program.

\section{Materials and methods}

The applied systems method was based on the systemic proceedings as a scientific method presented by Mazur (1976). The proceedings specify six stages (1-6), the first three of which are intended to solve cognitive problems. The remaining three stages deal with decision-making problems. In order, the stages are: exploration, classification, explication and postulation, optimisation, realisation.

Fig. 2. Translation of the general theoretical systemic proceedings/practice (Mazur, 1976) into author's educative method (own study based on Mazur 1976)
SYSTEMIC PROCEEDINGS - GENERAL THEORY

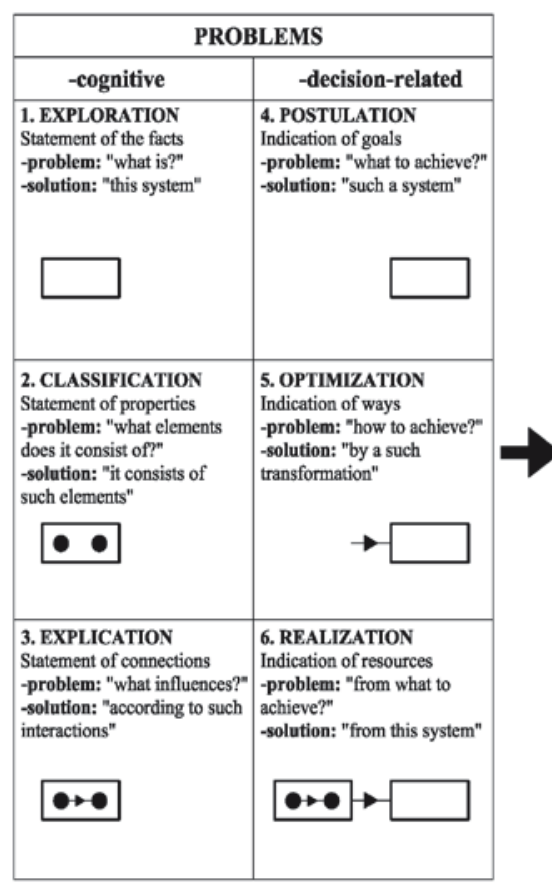

SYSTEMIC PROCEEDINGS APPLIED BY THE AUTHOR IN EDUCATIVE PROCESS (based on general theory)

\begin{tabular}{|c|c|}
\hline \multicolumn{2}{|c|}{ PROBLEMS } \\
\hline -cognitive & -decision-related \\
\hline $\begin{array}{l}\text { 1. EXPLORATION } \\
\text { Statement of the facts } \\
\text {-problem: "what is?" } \\
\text {-solution: the general systemic model } \\
\text { of environmental factors and city } \\
\text { structure" (fig.3a) } \\
\text {-educative way to } \\
\text { explain/solve the problem: } \\
\text { lectures on general issues conc. } \\
\text { relationships between climatic factors } \\
\text { and shaping of the city structure }\end{array}$ & $\begin{array}{l}\text { 4. POSTULATION } \\
\text { Indication of goals } \\
\text {-problem: "what to achieve?" } \\
\text {-solution: a solar house fulfilling } \\
\text { appropriate project goals ( } 4 \mathrm{a}-4 \mathrm{~d}) \\
\text {-educative way to solve the problem: } \\
\text { common (teacher +students) defining } \\
\text { the goals appropriate for solar } \\
\text { architecture on basis of the theoretical } \\
\text { knowledge from lectures and the } \\
\text { analysis of the design location condit. }\end{array}$ \\
\hline $\begin{array}{l}\text { 2. CLASSIFICATION } \\
\text { Statement of the facts } \\
\text {-problem: "what element does it } \\
\text { consist of?" } \\
\text {-solution:the detailed systemic model } \\
\text { of environmental factors and city } \\
\text { structure" (fig.3b) } \\
\text {-educative way to } \\
\text { explain/solve the problem: } \\
\text { lectures conc. selected elements in }\end{array}$ & $\begin{array}{l}\text { MIZATION } \\
\text { in of ways } \\
\text { n: "how to achicve?" } \\
\text { : indication of the } \\
\text { ays for } \\
\text { the goals (4a-4d)- tab.1 } \\
\text { mn) } \\
\text { ve way to solve the problem: } \\
\text { ce of design tasks in variated } \\
\text { cales (task 1-3) }\end{array}$ \\
\hline $\begin{array}{l}\text { 3. EXPLICATION } \\
\text { Statement of connections } \\
\text {-problem: "what influences?" } \\
\text {-solution: defining the interactions in } \\
\text { the systemic model between selected } \\
\text { elements of the system (fig. } 3 \mathrm{c} \text { ) } \\
\text {-educative way to } \\
\text { explain/solve the problem: } \\
\text { lectures focused on the relationships } \\
\text { between elements of the system } \\
\text { (conc.3 desing scales) }\end{array}$ & $\begin{array}{l}\text { 6. REALIZATION } \\
\text { Indication of resources } \\
\text {-problem: "from what to } \\
\text { achieve?" } \\
\text {-solution: applied design solutions } \\
\text { including elements specified in } \\
\text { explication model (fig.3c) - tab.1 } \\
\text { (right column) } \\
\text {-educative way to solve the problem } \\
\text { incorporation of the optimization } \\
\text { stage results in a solar house design } \\
\text { and its surroundings (3-d model) }\end{array}$ \\
\hline
\end{tabular}


According to this method, cognitive problems refer to the existing reality their solution can be arrived at only by means of theoretical explanation and it doesn't change the existing state. Decision-related problems are design problems - their solution thus relies upon making proper decisions taking into account the knowledge from the previously solved cognitive problems - their solution changes the existing state.

The scientific method (validated in architectural field in e.g. Marchwiński (2005), Szparkowski (1978)) has been translated into the author's educative method related to the topic of solar building design (Fig. 2).

\section{Cognitive problems and explanation thereof}

The explanation of cognitive problems was based on a series of lectures. These were arranged on a "general to detailed" basis, thus imitating the structure of the models discussed below (Fig. 3). Thanks to the models, the issues discussed during the lectures were limited only to those which were necessary for attaining the didactic goal and providing satisfactory (according to the author) knowledge for the solar house design. Firstly, the lectures dealt with spatial planning, then urban planning, focusing on the relationships between climatic factors and the city structure. The majority of time was allocated to the final lectures. These referred to the architectural design of solar buildings. A separate lecture was given to BIPV issues. The more detailed proceedings in relevant order can be described as follows:

Exploration stage (1) - during this first stage of the systems method, the solution of the cognitive problems is the answer to the question "what is?" In response to this question, the systemic model was defined as a set of two overarching systems that characterise environmental design, i.e. the natural system and the built-up system. By adapting this set of systems, the design task was narrowed down to two components: environmental factors and city structure (Fig. 3a). Thus, lectures focused on the general issues concerned with these two elements and provided necessary theoretical background to the students.

Classification stage (2) answers the question "what elements does it consist of?" Thus, this stage requires a more detailed outlook on the issues discussed during the exploration stage. To answer this question, a detailed systemic model developed by Zielonko-Jung (2013) was used. The model presents the elements the environmental factors and city structure consist of. In order to simplify the design task, the issue was further limited by extracting climatic factors, as they are the most vital in shaping solar architecture, from a wide set of environmental factors (Marchwiński, 2005; Marchwiński \& Zielonko-Jung, 2005). In turn, the urban structure was divided into spatial planning (district), urban planning (housing estate) and architectural (building) scales. Research (Bala, 2010; Zielonko-Jung, 2013;Zielonko-Jung \& Marchwiński, 2017) has revealed that consideration of the relationship between the climate and the city building (including the solar building) requires analysis that accounts for the above scales (Fig. 3b).

Explication (3) can be regarded as the most important stage of the explanation of cognitive problems, as it refers to a statement of connections, i.e. interactions that occur in the systemic model (the statement is an essence of the systems method itself). The complexity of these relationships requires multidisciplinary research. However, in order to make use of the advantages of the systems method, the problems were significantly simplified so as to adjust them to the capabilities of students. An original model was created (Fig. 3c) with the selection of elements which, according to the author, were particularly important to the implementation of the design task. These elements were extracted at each level of the scale (district level, housing estate level and building level). The actions defined on the system (arrows) provided a basis for the final lectures. Unlike in the traditional method, which focuses on a detailed and extensive description 
Fig. 3. Systemic models: a) exploration model, b) classification model, c) author's own explication model resulting from the a and $\mathrm{b}$ models, applied as an educative tool for solar PV integrated building design on design classes within the "Environmental Design" subject (own study based on Mazur 1976) of all elements of the system, the lectures concentrated on explaining the interactions between them (e.g. the influence of insolation on the geometry of the buildings rather than theoretical elaboration of types of building geometries). Such an approach significantly shortened the lectures and, above all, lead to an understanding of the mechanisms that occur in the system model, and as a result, enabled the skilful (conscious) implementation of design solutions at the stage of solving decision-related problems.
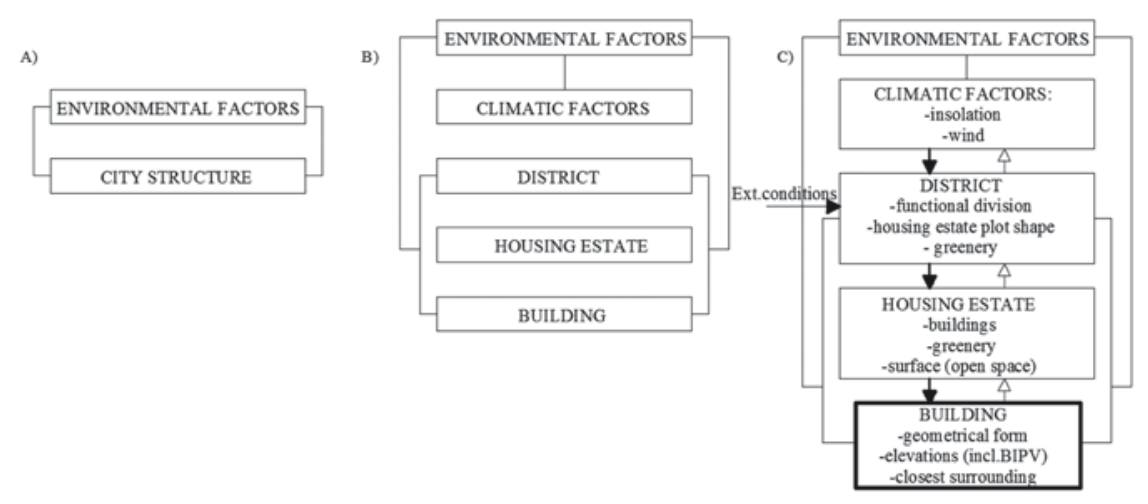

\section{Decision-related problems and solutions thereof}

The decision-related problems were solved on the basis of three design tasks, the first two of which were intermediate tasks that led to the implementation of the final task.

The first task (task 1) referred to the planning scale. The onset materials included a map of a fragment of a selected city. For analysing the external conditions read from the map, as well as additional input data (including the set direction of winter and summer winds and basic solar exposure parameters), it was necessary to select an area for the project specified in Task 2. It was necessary to remodel the layout of the building development and, above all, to remodel the greenery as it is the significant factor that exerts an impact on the effects the sun and winds have on the building. In addition, a favourable motorway route had to be selected. The aim of this extra requirement was to simulate the complexity of urban phenomena - the influence of a motorway, as a factor from beyond the system defined in Fig. 3c (called - "external conditions") was introduced at the planning level.

Another design task was to create a simplified design of a solar housing estate located in the selected area in the ambient conditions discussed and developed in Task 1.

Having implemented the above tasks and on the basis of the outcomes thereof, students proceeded to implement the final result (design of the solar single-family building with BIPV).

The first task was implemented by making plans with the use of the aforementioned map of a fragment of Bytom, Poland $(1: 10,000)$. Functional zones in the area were designed, along with a highway.

Two further tasks were realised in the form of $3 d$ models at scales of 1:500 and $1: 50 / 100$, respectively. In the case of the final task, for simplification, its scope did not include the internal structure of the building.

All the design processes followed the previously mentioned systemic proceedings developed according to Mazur: postulation, optimisation and realisation.

Postulation (4) is an indication of goals. Thus, postulation may be seen as the first stage of the decision-making process. In terms of the educational process in question, it is an indication of project goals. The identification was possible thanks 
to theoretical knowledge acquired by the students (previous stages: cognitive problems explanation). The knowledge made students aware of the goals and enabled their participation in the definition of these goals. This is also an effect of the analysis of the design location conditions. The main goals included:

- creating favourable conditions for the use of solar energy in the designed single-family building for heating purposes with the aid of passive solar measures (goal 4a);

- creating architectural solutions for protection against loss of thermal load and the overheating of rooms, as well as creating conditions for natural air conditioning - the use of natural ventilation and passive cooling (goal 4b);

- multifunctional application of PV technology as BIPV (goal 4c);

- mitigation of the negative impact of the planned motorway as a source of noise and pollution (goal $4 \mathrm{~d}$ connected with an impact from beyond the system).

The determination of the theoretical model of a solar house that fulfils the above-mentioned project goals can be treated as solution to the postulation stage. Thus, the solution made it possible to proceed to the subsequent stages of the systems method.

Optimisation (5) is an indication of ways to achieve the defined goals. To simplify the design tasks, optimisation actions were limited to simple actions, i.e., unidirectional actions (arrows in bold, Fig. 3c). According to the model, each of the following three design tasks influenced the design solutions adopted in the subsequent task. Thanks to this correlation, the final project - solar single-family house-emerges as a result of solutions (optimisation activities) on a planning and urban scale. Thus, its design solutions are not limited to the architectural scale, but rather take into account the relationship with the environment on macro and micro scales. The solution to the optimisation stage was supposed to provide a response to the question of what should be done - i.e. what design solutions (optimisation methods) should be introduced in order to achieve the design goals.

Realisation (6) is an indication of the resources required for attaining the specified goals, i.e. the implementation of the indicated optimisation methods. While applying the systems method, it is possible to collate the resources listed

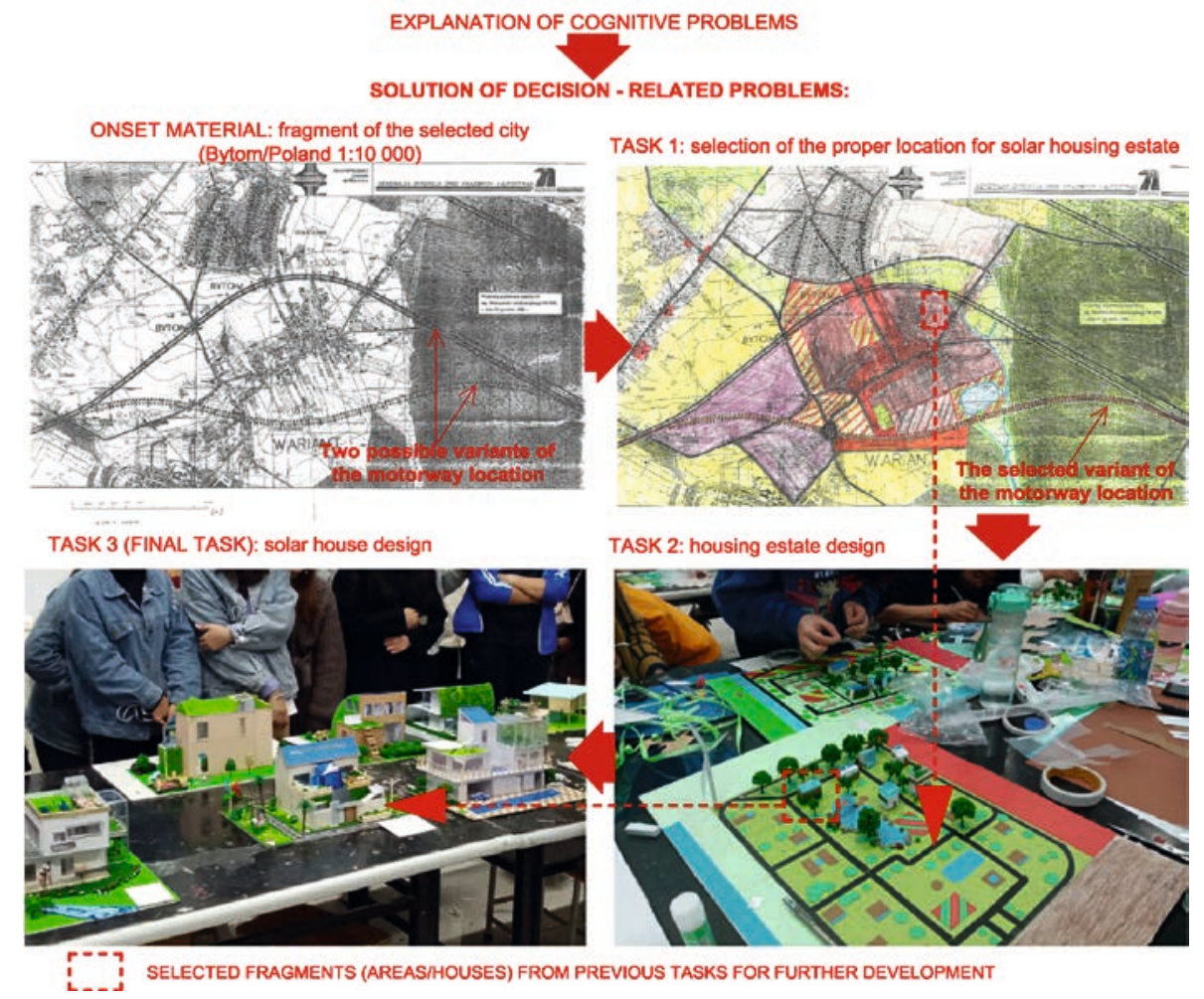

Fig. 4. Design tasks (1-3) - design process leading to the solution of decision-related problems (photos by the author) 
in the systemic model (Fig. 3c) that enable the implementation of the design goals determined at the postulation stage.

The optimisation and realisation measures introduced by the students in their designs are described in the Results section.

\section{Results}

The ultimate architectural concept of the solar single-family house provided the final result of the design task.

Numerous optimisation and realisation methods that resulted in various architectural concepts have been presented above. The concepts largely depended on the designer's creative imagination, which is natural for architecture as a discipline. However, the systems method imposed very well-ordered design stages. As the optimisation methods had to respond to the previously defined design goals (resulting, in turn, from the cognitive stage: items 1-3), there was no possibility to ignore the prior design assumptions. All the design actions were strictly embedded in the developed system model, rather than being from beyond the model.

Examples of the final design results, namely optimisation and realisation solutions, are presented in Table 1.

Fig. 5. Selected final designs of one-family solar building with solutions corresponding to the project goals (photos by the author)

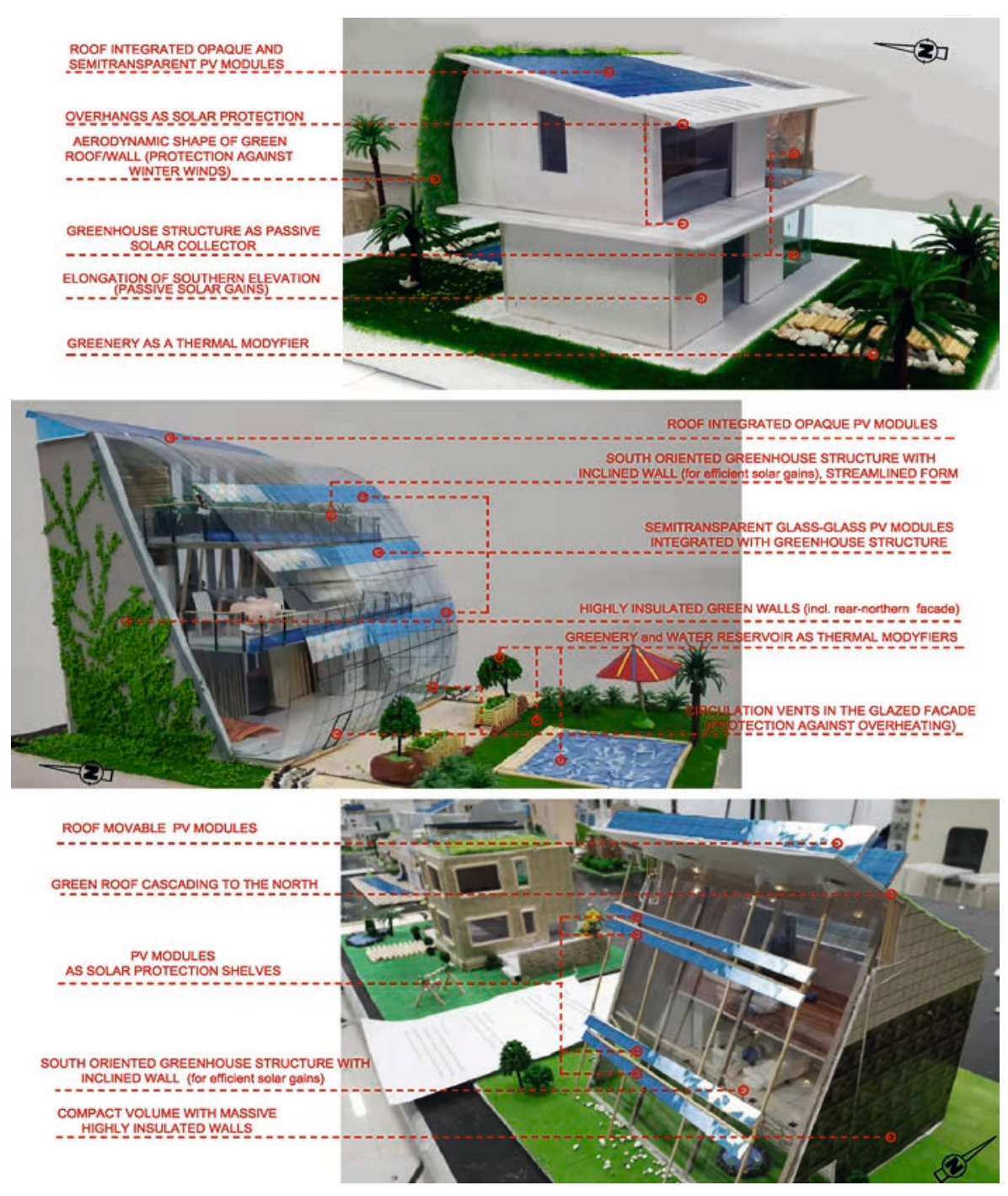


Table 1. A list of the selected optimisation and realisation solutions derived from the design tasks

(own study)

\begin{tabular}{|c|c|}
\hline OPTIMISATION & $\begin{array}{c}\text { REALISATION } \\
\text { (elements in bold are extracted from Fig. 3c) }\end{array}$ \\
\hline $\begin{array}{l}\text { ways of attaining goal 4a: } \\
\text { - selecting a plot of land for a } \\
\text { housing estate exposed to } \\
\text { solar radiation; } \\
\text { - extending the layouts of } \\
\text { buildings on the E-W axis in } \\
\text { order to create the maximum } \\
\text { surface of the southern } \\
\text { façades, as they are the most } \\
\text { exposed to solar energy; } \\
\text { - southern orientation of the } \\
\text { greenhouse structure; } \\
\text { buildings arranged in such } \\
\text { a way as not to shade each } \\
\text { other from the expected solar } \\
\text { gains; } \\
\text { the use of a terrain surface } \\
\text { that boosts solar inflow to the } \\
\text { building through reflection } \\
\text { from the south. }\end{array}$ & $\begin{array}{l}\text { resources for attaining goal } 4 \text { a (selected measures): } \\
\text { functional division: functional zoning - the area intended } \\
\text { for the housing estate located in a buffer zone of greenery, } \\
\text { away from the highway, bordering on areas with } \\
\text { non-burdensome and low-rise building development that } \\
\text { does not shade the intended housing estate area; } \\
\text { housing estate plot shape: the plot stretching on E-W axis, } \\
\text { which enables the creation of building layouts with long } \\
\text { southern facades; } \\
\text { buildings: array systems - terraced buildings stretching on } \\
\text { the E-W axis, cascading towards the north; } \\
\text { greenery: on the southern side, no trees or only deciduous } \\
\text { trees (which cause no obstacles to winter sunlight); } \\
\text { surface (open space) \& building closest surrounding: in } \\
\text { the zones adjacent to the facade from the south - white } \\
\text { gravel, paving slabs in bright colours; } \\
\text { geometrical form: inclination of the southern elevation } \\
\text { towards sunlight (increasing the efficiency of solar gains); } \\
\text { elevations: as above plus increased ratio of glazing from the } \\
\text { south (greenhouse structures external walls). }\end{array}$ \\
\hline $\begin{array}{l}\text { ways of attaining goal } 4 \mathrm{~b} \text { : } \\
\text { use and development of } \\
\text { greenery systems as a shelter } \\
\text { against winter winds; } \\
\text { creation of array systems of trees } \\
\text { that form ventilation tunnels - } \\
\text { the use of summer winds; } \\
\text { - increasing the ratio of } \\
\text { biologically active surfaces; } \\
\text { the use of trees as a } \\
\text { sunscreen in the summer and } \\
\text { as a thermal insulator in the } \\
\text { winter; } \\
\text { adapting the building to } \\
\text { natural ventilation; } \\
\text { creating forms that are energy- } \\
\text { saving and capable of reducing } \\
\text { the impact of winter winds. }\end{array}$ & $\begin{array}{l}\text { resources for attaining goal } 4 \mathrm{~b} \text { (selected measures): } \\
\text { - functional division: functional zoning - the area intended } \\
\text { for the housing estate located in a buffer zone of greenery } \\
\text { (perpendicular to the direction of winter winds) and exposed } \\
\text { to summer winds;, } \\
\text { - district greenery: supplementing and fortifying the existing } \\
\text { high greenery areas (forming the green shelter) with } \\
\text { coniferous trees; } \\
\text { - buildings: array systems - buildings designed parallel to the } \\
\text { direction of summer winds (forming air corridors); } \\
\text { - housing estate greenery: deciduous trees in front of the } \\
\text { southern facade as protection against the summer sun, } \\
\text { clusters of coniferous greenery as a thermal buffer, array } \\
\text { greenery along communication routes on the E-W axis (air } \\
\text { corridors); } \\
\text { surface (open space): situating water reservoirs and green } \\
\text { areas near buildings for passive cooling of buildings in the } \\
\text { summer; } \\
\text { geometrical form: streamlined forms with compact plans } \\
\text { (circle, square or suchlike), roofs cascading towards the } \\
\text { north; } \\
\text { elevations: circulation vents in the facade, solar protection } \\
\text { systems on the southern, western and eastern façades, } \\
\text { green roofs and walls. }\end{array}$ \\
\hline $\begin{array}{l}\text { ways of attaining; goal 4c: } \\
\text { - integration of PV systems } \\
\text { with the building, applied as } \\
\text { the solar protection element } \\
\text { (including the integration with } \\
\text { a greenhouse structure). }\end{array}$ & $\begin{array}{l}\text { Resources for attaining goal 4c (selected measures): } \\
\text { - geometrical form: inclination of walls with PV modules - } \\
\text { adapting PV systems to energy requirements; } \\
\text { - elevations: use of semi-transparent glass-glass PV modules } \\
\text { as elements of the greenhouse structure or roof skylights; } \\
\text { - the use of PV modules in the form of external solar } \\
\text { protection shelves - the so-called shadowvoltaic system. }\end{array}$ \\
\hline $\begin{array}{l}\text { ways of attaining goal } 4 \mathrm{~d} \text { : } \\
\text { defining a long distance } \\
\text { between the motorway and } \\
\text { the plot at which the housing } \\
\text { estate is to be built; } \\
\text { creating buffer zones in the } \\
\text { proximity of the motorway. }\end{array}$ & $\begin{array}{l}\text { resources for attaining the goal } 4 \mathrm{~d} \text { (selected measures): } \\
\text { - functional division: functional zoning - areas near the } \\
\text { motorway intended for industrial purposes, services harmful } \\
\text { to habitation or as open areas; } \\
\text { district greenery: thick arrays of coniferous trees along the } \\
\text { highway. }\end{array}$ \\
\hline
\end{tabular}

The concepts of solar buildings illustrated in the examples (Fig. 5) depict a diverse design approach while meeting the common goals assumed in the task. Taking into account the relationship of the building with the surroundings, which results from the preceding partial tasks, it is mainly Task 2 (imposed by the system model) that is a characteristic feature of the approach. The foreground of buildings constitutes a solar architecture element in mutual interaction with the 
Fig. 6. Possible impacts on the solar building and areas of optimisation (circles) within the author's own systemic model (own study) building. Moreover, the diversity in shaping spatial forms as a response to the $4 \mathrm{a}$ and $4 \mathrm{~b}$ goals is noticeable in the approach. The introduction of greenhouse structures as passive solar measures largely influenced the aesthetic function of buildings, and in some cases, it even defined their architecture. This enabled a better understanding of how important it is to sensitise architects to aesthetic issues while designing energy-saving structures, including solar facades (Marchwiński, 2021). Goal 4c has also been successfully achieved. Photovoltaic modules are used in a very diverse manner, but each time, a logical relationship with the architecture of the building is established. In the case of integration with greenhouse structures, this results from the operational needs regarding thermal and lighting issues, which enables understanding of the meaning and role of BIPV in architecture (Marchwiński, 2012).

\section{Discussion}

The design results showed that despite the shared design goals, their implementation is characterised by a great diversity of architectural solutions. Possible solutions concern such issues as the geometry of the body, features of the greenhouse structure and its integration with the building, development of the immediate surroundings, solar protection measures and the use of photovoltaic technology.

Based on the author's own systemic model (Fig. 3c), the final project of the single-family solar house emerged as a result of taking into account the solutions adopted in previous design tasks (district scale-task 1 and housing estate scaletask 2), enriched with more detailed solutions on an architectural scale.

Taking into consideration the above-mentioned solutions and using the systemic model, three main factors that influence the solar building design can be indicated. Each direct impact provides a field for design optimisation (Fig. 6).
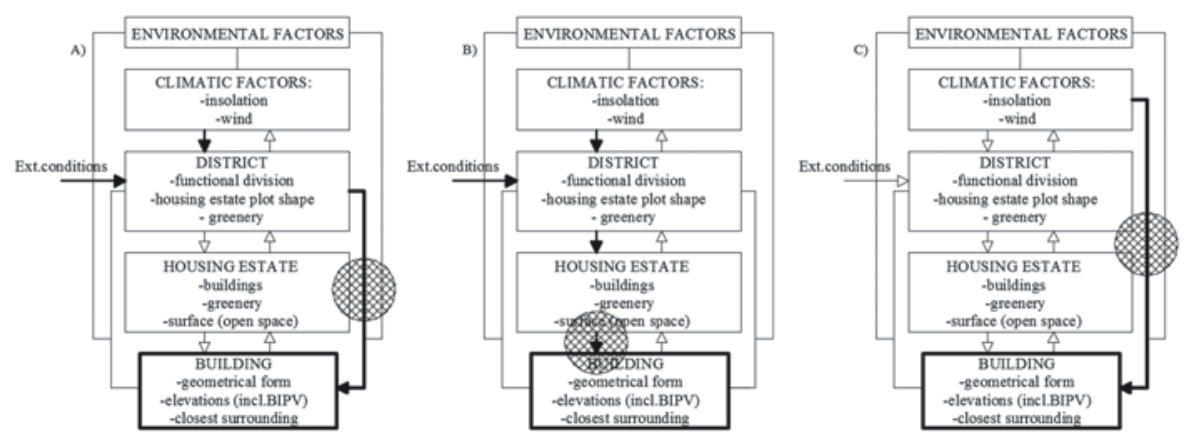

Figure 6a pictures a situation in which the solar building design is influenced by solutions at the macro-scale (district). These solutions result from climatic factors and external non-climatic conditions (e.g. motorway impact).

Such solutions may include, for example:

housing-estate plot shape - locating the building on the plot on E-W axis, which enables the implementation of building layouts with long southern facades (realisation of the goal $4 \mathrm{a}$ );

district greenery - the use of thick arrays of coniferous trees along the highway as a hygienic and acoustic buffer zone (realisation of the goal 4d); on the southern side, no trees or only deciduous trees (that cause no obstacles to winter sunlight) to provide optimised solar energy use in a building (realisation of goal $4 \mathrm{a}$ ).

Figure $6 \mathrm{~b}$ pictures an alternative situation. The solar building design is influenced by solutions at the micro-scale (housing estate). These, on the other hand, result from climatic and non-climatic external factors modified by the design solutions at the district scale. 
Such solutions may include, for example:

- buildings - array system with terraced building stretching on the E-W axis, cascading towards the north - favourable for creating solar facades (realisation of goal $4 \mathrm{a}$ );

- buildings - a building designed parallel to the direction of summer winds (forming air corridors) - advantageous for natural ventilation, solar energy use (realisation of the goal $4 b$ );

- surface (open space) - situating water reservoirs and green areas near the building for passive cooling in the summer (realisation of goal $4 \mathrm{~b}$ );

Figure $6 \mathrm{c}$ pictures the third alternative, in which the solar building design is directly influenced by environmental factors.

The design solutions based on that impact include, for example:

- geometrical form - inclination of the southern elevation towards sunlight increasing the efficiency of solar gains (realisation of goal 4a);

- elevations - the use of PV modules in the form of external solar protection shelves (the so-called shadowvoltaic system) in order to optimise solar energy use throughout the year (realisation of goal 4c);

- surface/building closest surroundings - in the zones adjacent to the facade from the south - white gravel, paving slabs in bright colours (realisation of goal 4a).

This applied method offered a holistic view of the issues of pro-environmental design and led to an understanding of the relationship between the urban scale and the scale of the building. This aspect was considered crucial in teaching sustainable development architecture. The design effects must be regarded as more than satisfactory, taking into account cultural and linguistic barriers and the lack of prior preparation of students in the field of architectural design. The method proved to be an effective educational tool. The success of the method can be determined by:

- the relatively short period of time needed for obtaining the assumed educational effects;

- acquiring the ability to solve multidisciplinary tasks (in different design scales);

- acquiring the ability to solve decision-related problems (making design decisions) by students who have not yet had a prior training in architecture.

In accordance with the assumptions adopted in the systemic model (Fig. 3c), the final design task excluded solutions for the functional layout of the internal space and construction issues. The systems method allows freedom of interpretation when making assumptions with reference to such issues. This enables flexible adaptation of the systems method to the profile and the scope of the design task. Based on the discussed system, the task can, in many ways, be transformed according to the assumed goals. The figures below present three examples of such possibilities.

Figure 7 a presents the task modification by introducing precise interactions within subsystems. This can be applied when the aim of the course is to teach students the topic of the relationship between the building and its closest surroundings.

When the goal is to examine the impact of the total climatic conditions on the building, the task may be modified by increasing the number of system elements, as seen in Figure $7 \mathrm{~b}$.

It is also possible to select a subsystem to serve as the subject of the study. By selecting a subsystem, such as that in Figure 7c, the goal of the task can lie in the identification of optimal urban solutions for a solar housing estate. 
Fig. 7. Examples of transformation possibilities of the author's own systemic model (own study)
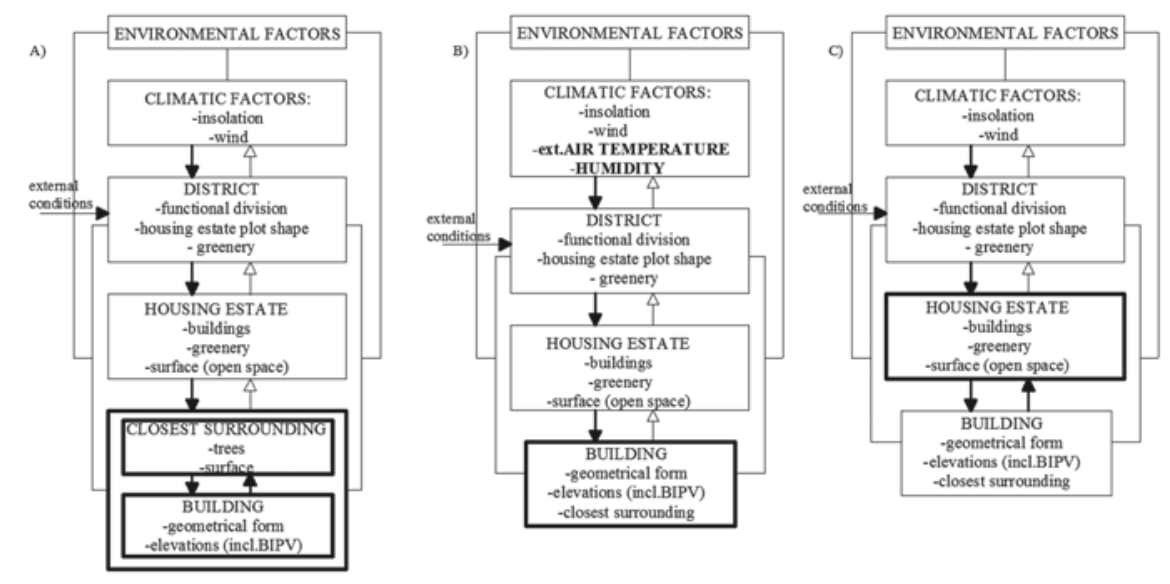

\section{Conclusions}

The article presents the application of the systems method in the educational process. Experience gained from the process leads to the general conclusion that the systems method is applicable in architectural teaching as it provides a way for a clear and simplified presentation of complicated and extensive issues. It is thus helpful in understanding the issues with relatively little substantive preparation and despite communication barriers and the time limits allocated for teaching. This is owing to the use of cybernetic schemes (system interactions) that provide an overview of the whole. For this reason, the method faces limitations in cognitive sciences, based on observational, empirical or statistical methods, i.e. those methods in which the aim is to describe and characterise a research subject in detail within monodisciplinary problems. It is also limited in a sense with regard to architectural education as it does not concentrate on theory of architecture in detail (the explanation of cognitive problems is not the final objective).

The systems method can be an adequate educative tool for solving multidisciplinary problems (in the discussed case - planning, urban, architectural, technological issues) and creating a joint research platform for multi-industry cooperation, including the postulated cooperation between architects and environmental engineers (Nyka, 2019) this seems especially suitable for sustainable architecture design.

Secondly, the method is characterised by brevity. It is particularly useful in searching for a set of solution possibilities because it guarantees completeness. In contrast to observational and empirical methods, no possibility is overlooked in the systems method. It eliminates freedom of interpretation in the course of solving problems. However, this freedom exists at the beginning when assumptions (i.e. systems, their elements and interactions) are being defined.

Perhaps the main advantage of the systems method lies in the fact that it teaches logical understanding of cause-and-effect relationships and it is partly independent from extensive cognitive (theoretical) knowledge, culture, and behaviour. The understanding of cause-and-effect relationships is particularly important in architectural design, including environmental design oriented towards solar PV integrated building design that should be seen as an element of the global sustainable development concept - a common directive for all mankind. 


\section{References}

Altun, M.C., Tyurkay, A. (2006). Integrated Design Process in Architectural Education: The Construction Project Studio Experience. In: Building our Future 2006: International Conference on Integrated Design (ID@50). Bath, UK.

Bala, H. A. (2010). Sustainability in the architectural design studio: a case study of designing on-campus academic staff housing in Konya and Izmir, Turkey. The International Journal of Art and Design Education, 29(3), 330-348. https://doi.org/10.1111/j.1476-8070.2010.01665.x

di Battista, V. (2006). Towards a Systemic Approach to Architecture. In: Systemics of Emergence: Research and Development, 391-398. DOI: 10.1007/0387-28898-8_27

Filho, W.L., Pallant, E., Enete, A., Richte, B., Brandli L.L. Planning and implementing sustainability in higher education institutions: an overview of the difficulties and potential. International Journal of Sustainable Development \& World Ecology, 25(8), 713-721. https://doi.org/10.1080/13504509.2018.1461707

Gürel, M.Ö. (2010). Explorations in teaching sustainable design: a studio experience in interior design/architecture. The International Journal of Art and Design Education, 29(2), 184-199. https://doi.org/10.1111/j.14768070.2010.01649.x

Hills, P. (2001). Environmental education, community mobilization and sustainable development in Hongkong: a comparative perspective. International Journal of Sustainable Development \& World Ecology, 8(2), 137-154. https://doi. org/10.1080/13504500109470071

Iwaro, J., Mwasha A., Williams, R. G., Wilson W. (2015). The role of integrated performance model in sustainable envelope design and assessment. International Journal of Sustainable Engineering, 8(4-5), 294-316. https:// doi.org/10.1080/19397038.2014.930211

Johannes, R. (1992). Architectural design: a systematic approach: part 1. Design Studies, 13(1), 71-86.

https://doi.org/10.1016/0142-694X(92)80006-K

Kerdanghan, S., da Silva, J.L. , Andres, L (2012). A systems approach to meeting the challenges of urban climate change. International Journal of Urban Sustainable Development, 4(2), 125-145.

https://doi.org/10.1080/19463138.2012.718279

Laszlo, E. (1996). The Systems view of the World. A Holistic vision of our time. Hampton Press 2nd ed.

Lee, Y,S. (2014). Sustainable design re-examined: integrated approach to knowledge creation for sustainable interior design. The International Journal of Art and Design Education, 33(1), 157-174.

https://doi.org/10.1111/j.1476-8070.2014.01772.x

Marchwiński, J. (2012). Fasady fotowoltaiczne. Technologia PV w architekturze. Warszawa: WSEiZ.

Marchwiński, J. (2005). Rola pasywnych i aktywnych rozwiązań stonecznych $w$ architekturze budynków biurowych i biurowo-przemystowych, praca doktorska. Warszawa: WAPW.

Marchwiński, J. (2021). Role and Factors of Solar Facades Shaping in Contemporary Architecture. Budownictwo i Architektura, 20(3), 43-56. https://doi.org/10.35784/bud-arch.2640

Marchwiński, J., Zielonko-Jung, K. (2005). Systematic approach to the evaluation of the solar measures' role in creating the architecture of office and office-industrial buildings. In: The 2005 World Sustainable Building Conference in Tokyo.

Mazur, M. (1976). Cybernetyka i Charakter. Warszawa: Państwowy Instytut Wydawniczy.

Nikken Sekkei. (2000). Amity with Environment. Toward creation of sustainable cities and buildings, In: Sustainable Building 2000: information materials available on International Conference, Maastricht, the Netherlands 22-25 October 2000. 
Nsanbayeva, Nurgul. (2019). A systems approach to sustainability in higher education: Analysis of undergraduate architectural education in Kazakh Leading Academy of Architecture and Civil Engineering in Kazakhstan. Aalto University, School of Arts, Design and Architecture.

Nyka, L. (2019). Bridging the gap between architectural and environmental engineering education in the context of climate change. World Trans. on Engng and Technol. Educ., 17(2), 204-209.

Polański, Z. (1978). Wspótczesne metody badań doświadczalnych. Warszawa: Wiedza Powszechna.

Poveda, C.A., Lipsett, M. G. (2014). An integrated approach for sustainability assessment: the Wa-Pa-Su project sustainability rating system. International Journal of Sustainable Development \& World Ecology, 21(1), 85-98. https://doi.org/10.1080/13504509.2013.876677

Richter, B.W., De Sousa, L.O. (2019). The implementation of environmental education to promote sustainability: an overview of the processes and challenges. International Journal of Sustainable Development \& World Ecology, 26(8), 721-732. https://doi.org/10.1080/13504509.2019.1672220

Sandri, O.J. (2013). Threshold concepts, systems and learning for sustainability. Environmental Education Research, 19(6), 810-822. https://doi.org/10.10 80/13504622.2012.753413

Sevaldson, B. (2008). A system approach to design learning. In: System thinking and Integral Design. Offenbach: Achim Menges Ed.

Shulla K., Filho W.L., Lardjane S., Sommer J.H., Borgemeister C.(2020). Sustainable development education in the context of 2030 Agenda for sustainable development. International Journal of Sustainable Development \& World Ecology, 27(5), 458-468. https://doi.org/10.1080/1 3504509.2020 .1721378

Stiny, G., Mitchell, W.J. (1978). The Palladian grammar. Environment and Planning $B, 5,5-18$.

Szparkowski, Z. (1978). System ekologiczny architektury zakładu przemystowego. Warszawa: OWPW.

Togo, M., Lotz-Sisitka, H. (2013). Exploring a systems approach to mainstreaming sustainability in universities: a case study of Rhodes University in South Africa. Environmental Education Research, 19(5), 673-693. https://doi.org /10.1080/13504622.2012.749974

Wilisz, J. (2019). Argumenty uzasadniajace konieczność nauczania cybernetyki (Arguments for Necessity of Teaching Cybernethics). Edukacja-TechnikaInformatyka, 2(28), 140-147.

Zielonko-Jung, K. (2019). Aerodynamics in the education of prospective architects. World Trans. on Engng and Technol. Educ., 17(4), 471-476.

Zielonko-Jung, K. (2013). Ksztattowanie architektury ekologicznej w strukturze miasta. Warszawa: OWPW.

Zielonko-Jung, K., Marchwiński, J. (2017). Aspekty środowiskowe ksztattowania zabudowy w przestrzeniach miejskich. In: Innowacyjne wyzwania techniki budowlanej. Problemy naukowe budownictwa. Collective work edited by L. Czarnecki, Krynica-Zdrój, 127-142. 